Pregledni znanstveni rad DOI: $10.17234 /$ Croatica.42.19

UDK: 811.163.42(091)

821.163.42.09Čevapović, G.

811.163.42-05Boranić, D.

Primljen: 9. I. 2018.

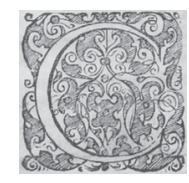

Prihvaćen: 29. I. 2018.

\title{
GRGUR ČEVAPOVIĆ I DRAGUTIN BORANIĆ
}

\author{
Josip Lisac \\ Odjel za kroatistiku i slavistiku Sveučilišta u Zadru \\ jlisac@unizd.hr
}

U radu se prikazuje rad hrvatskoga pisca iz prve polovice 19. stoljeća Grgura Čevapovića (1786-1830) i hrvatskoga jezikoslovca Dragutina Boranića (1876-1955), koji je u ranoj fazi svoga rada vrlo lucidno prikazao Čevapovića i njegov hrvatski jezik. Zaključio je Boranić da je Čevapović pisao jezikom kojim Hrvati uglavnom pišu i u njegovo doba (1898), a to je ostalo nedovoljno zapaženo sve do danas. Dakle, u hrvatskim standardizacijskim procesima potkraj 18. stoljeća i na početku 19. stoljeća bilo je vrlo znatno mjesto Grgura Čevapovića, a u tom nije bilo dovoljno uočeno ni njegovo mjesto ni mjesto Dragutina Boranića.

Ključne riječi: Čevapović, Boranić, drama, hrvatski jezik

Grgur Čevapović (1786-1830) bio je slavonski franjevac, pisac, povjesničar i kulturni djelatnik, gvardijan i provincijal. Pisao je na latinskom i na hrvatskom jeziku, među ostalim na latinskom o franjevačkim književnicima Stjepanu Vilovu, Emeriku Paviću, Ivanu Velikanoviću, Marijanu Lanosoviću i drugima. Priređivao je za tisak Katančićev prijevod Biblije, pri čemu su njegov posao nakon njegove smrti nastavili Josip Matzek i Adalbert Horvat, pisao je i o Katančićevu leksikografskom radu. S Tomom Košćakom, zagrebačkim školskim nadzornikom, raspravljao je o grafijskim pitanjima zalažući se za slavonski slovopis i za povezivanje hrvatskih zemalja. Zanimljivo je da u svojoj knjižici na hrvatskom (Josip, sin Jakoba patriarke) Čevapović navodi 
(str. 13) kako je djelo oblikovao prema grafiji Šime Starčevića, a spominje Starčevićevu knjižicu iz 1816. vrlo pohvalnim riječima, ali bez spomena njegova imena. Posebno je važan po tome što je na mladome novoštokavskom standardu napisao dramski tekst Josip, sin Jakoba patriarke (Budim, 1820). U metričkim pitanjima pozivao se u predgovoru te drame na Ignjata Đurđevića i osporavao Matiju Petra Katančića. Poznavao je i neke druge (južno)hrvatske pisce, pri čemu je bio posebno oduševljen Kanižlićevim djelom Sveta Rožalija nastalim i pod dubrovačkim utjecajem.

Godine 1992. objavljen je pretisak budimskoga izdanja koji je pripremio za tisak i kojemu je pogovor napisao Josip Bratulić.

Godine 1990. objavljen je u Osijeku Zbornik radova o fra Grguru Čevapoviću gdje nalazimo i prinose Nikole Batušića, Dubravka Jelčića, Stjepana Babića, Mije Lončarića, Josipa Vončine, Rafe Bogišića, Ante Sekulića i drugih istraživača.

Lončarić tumači kako Čevapović piše onim hrvatskim književnim jezikom koji će ubrzo postati zajednički književni jezik svih Hrvata, pri čemu utjecaj dijalekatne osnovice (požeškoga govora) nije velik. Ukazuje i na Maretićevu obradbu (i) Čevapovićeva jezika (Maretić 1910).

Vrlo visoko cijeni Čevapovićev jezik i Stjepan Babić koji ističe da on "piše prirodno, glatko, leksički i frazeološki bujnim jezikom u kojem nema mucavosti ni ukočenosti" (1990: 144).

Nikola Batušić bilježi datume kada je u Vukovaru 1819. izvođena Čevapovićeva drama, a davana je i naknadno postavši pravi repertoarni uspjeh. Pritom po prvi put $u$ hrvatskom teatru Čevapović kao redatelj na pozornicu dovodi glumice, ne kao u prošlosti kada su ženske uloge igrali preodjeveni mladići. Pokazuje se Čevapović kao pravi znalac pozornice, a na njega je osobito utjecala hrvatska isusovačka drama. Čevapović očito najavljuje hrvatski narodni preporod. On uvodi i glazbene dijelove u dramski tekst koji predstavlja "zreli domet završne faze sjevernohrvatske školske drame i zaključuje onu razvojnu etapu hrvatskoga glumišta koja je početkom 13. stoljeća započela u zagrebačkom isusovačkom kolegiju" (Batušić 1990: 103).

Stih i strofu Čevapovićeve drame svestrano je i opsežno analizirao Pavao Pavličić (1996). Zaključio je kako Čevapović

nije prethodnik preporodnog gibanja samo po tome što je imao osjećaj za jedinstvo svih hrvatskih krajeva (koje, uz to, i zove ilirskima), nego i po tome što je bio svjestan kako pri stvaranju nove književnosti treba postupati svjesno, kako treba ogledati izvore i argumente, a potom načiniti najbolji izbor, opredijeliti se za najefikasnije principe (1996: 183). 
Štoviše, Pavličić Čevapovićev tekst zove slavnom dramom (1996: 155).

Istraživači kao Babić i Pavličić najavljuju da će se proučavatelji povijesti hrvatskoga jezika i povijesti hrvatske književnosti Čevapovićevu djelu još vraćati, a to je svakako istina i do toga je i došlo.

Sve to, naravno, ne znači da o Čevapovićevu dramskom djelu nije pisano i prije novijih istraživanja. Takvih je proučavanja bilo dosta u drugoj polovici 19. stoljeća i u prvoj polovici 20. (Ivan Scherzer, Đuro Grubor, Julijan Jelenić, Ivan Esih, Tomo Matić itd.), a pisao je o njemu 1899. i Dragutin Boranić (1870-1955), poznati hrvatski jezikoslovac, te Silić (1993) i Samardžija (2001). Kako je taj Boranićev članak vrlo zanimljiv i nedovoljno zapažen, reći ćemo o njemu pokoju riječ u ovom prinosu posvećenu kolegi i prijatelju Ivi Pranjkoviću koji se, naravno, u svom radu sretao i s Boranićevim djelom, poglavito s njegovim pravopisnim prilogom, kao i sa slavonskim jezičnim i književnim radom.

Boranićev tekst počinje vrlo živo i temperamentno, pri čemu misli da je do izvedbe došlo jedne vukovarske večeri u listopadu 1819, a odigran je u srpnju te godine. Točan je Boranićev podatak da je Čevapovićeva predstava organizirana u čast biskupu đakovačkom Emeriku Karlu Rafaju. Kad se podigao zastor, na pozornicu su došle krasotice vila Dalmatinka i vila Srijemka, a one su čule kako ostale vile slovinske čekaju na njih da zajedno pjevaju. Pozornicu je ubrzo napunilo raznoliko mnoštvo, pa je gledatelj mogao pomisliti da je u dolovima hebronskim ili pod piramidama. Kad je pak odjeknula pjesma, bilo je jasno da je riječ o posavskom selu. Pjesma zbora uznosi "slavu i jedinstvo ilirskoga plemena" (Boranić 1899: 1), a to nije doneseno "manje krepko" (ibid.) nego u programu najsmjelijih iliraca. Sve se to izricalo u Slavoniji "gdje još nijesu bile iščezle uspomene na turske čalme" (ibid.), dok se Boranić pita je li publika razumjela te ideje iz pretpreporodnoga vremena. Kazuje da je autor toga priloga daroviti franjevac Grgur Čevapović i o njemu donosi osnovne podatke: o rođenju u okolici Požege i o smrti u Budimu, o školovanju i o doktoratu teologije, o latinski pisanim djelima. U tim djelima piše on "o starinama i povjesti, geografiji i književnosti naše domovine" (ibid.), a da je živio dulje, bio bi "jedan od stupova Gajeva ilirizma u Slavoniji” (ibid.), pa je Gaj i donio dio prologa i nešto stihova u Danici 1836. Zanimljivo je da je Gaj mijenjao Čevapovićeve stihove u skladu sa svojim gledanjima, a tako su već prije (1831) postupili u Srpskom letopisu gdje su ikavski tekst ekavizirali, ilirički mijenjali u serbijanski i slično (Bratulić 1992: 15). Piše Boranić da je Čevapovićeva drama tiskana 1820. u Budimu, da nije podijeljena na činove već na deset 
"ulaza" (prizora). Sadržaj tih prizora prepričava Boranić i upozorava na sličnost Čevapovićeva djela i južnohrvatskih nabožnih "skazanja", a i pisaca iz Slavonije Ivana Velikanovića i Aleksandra Tomikovića. Čevapovićeva drama ostaje nam "mila već i po tom, što je s njome božica Talija prvi put stupila na slavonsko tlo" (Boranić 1899: 1). Misli Boranić da Čevapović starohrvatske reprezentacije nije poznavao, a da Velikanovića i Tomikovića "kud i kamo nadvisuje u svemu" (ibid.). Slaže se sa starijom literaturom da je Josip, sin Jakoba patriarke najljepša crkvena drama u hrvatskoj književnosti. Ipak drži da to nije prava drama već da je riječ o nizu slika, a da su te slike "kadšto ispunjene živim momentima" (ibid.). U drami Čevapović nalazi 32 osobe, a trebale bi biti 33 (Batušić 1996: 97). Dijalog je, drži Boranić, "živahan i nigda predug" (ibid.), a prolog je "moderan! U njemu se pred nabožnim činom spominju cijela narodnosna i politička pitanja!" (Boranić 1899: 2). U pjesmama uočava Boranić utjecaj narodne pjesme i Reljkovića, a Čevapovića naziva bogodanim pjesnikom. To, dakako, ipak ne znači da bismo Boranića mogli držati velikim pjesnikom.

Sve ovo prije svega pišemo zato što je Boranić neobično lucidno pisao o Čevapovićevu jeziku: "Pohvale je vrijedan i jezik Čevapovićev, neobično čist, tako, te u tom zaostaju za njim predšasnici njegovi Kanižlić, Reljković i Katančić. Dok ovi u svom jeziku još čuvaju osebine slavonskog idioma, Čevapović pjeva jezikom od prilike onakvim, kakvim i mi danas pišemo, ako izuzmemo ikavski izgovor, kojim se služi i on poput svojih zemljaka. Po tom je Čevapović i u jezičnom pogledu ponekuda prethodnik ilirizma u Slavoniji" (ibid.). Znamo li što su o tom pitanju pisali od konca šezdesetih godina 20. stoljeća Dalibor Brozović (1969) i drugi, jasno je da je Boranić prethodnik njihovih gledanja, također i prethodnik nauka Krune Krstića (1942).

Najveću pažnju poklonio je Boranić Čevapovićevim popjevkama, pri čemu misli da su vukovarski učenici i učenice "izvodili nešto nalik na operu" (ibid.), a tako je mislio i Scherzer (1896) prije Boranića. Pomišlja Boranić i na Čevapovićeve uzore, ali drži da će to pitanje riješiti "naši muzikolozi" (ibid.). Doista je tu problematiku u velikoj mjeri osvijetlio Lovro Županović (2001).

Zaključuje Boranić da bi tiskano Čevapovićevo djelo "postalo omiljenim štivom našega puka" (ibid.). Zanimljivo je što bi Boranić pri novoj objavi promijenio. Misli da bi "trebalo tek pravopis navrnuti na današnji i izostaviti možda prolog, koji je sa svojim idejama god. 1819. došao prerano, a danas bi došao - prekasno" (ibid.). Razumije se, Boranić tu slovopis zove 
pravopisom, kako je u doba pisanja njegova članka bilo u običaju. Naravno, prolog nikako ne bi trebalo izostavljati jer je itekako zanimljiv, pa je potrebno da bude dostupan zainteresiranima.

Dragutin Boranić ponajprije je bio pravopisac (Silić 1993; Samardžija 2001), autor što je desetljećima u 20. stoljeću priređivao hrvatski pravopis kao nasljednik Ivana Broza i priređivač njegova Hrvatskog pravopisa iz devedesetih godina 19. stoljeća. Među znanstvenim radovima Boranićevima ističu se prinosi $O$ refleksivnim glagolima u hrvatskom jeziku (1899), Onomatopejske riječi za životinje u slavenskim jezicima (1909) te Vukovi Daničićev prijevod biblijskih citata (1925). To su prilozi ozbiljne znanstvene vrijednosti, a i njegovi prikazi tada aktualnih jezikoslovnih izdanja vrlo su korisni. Kao što iz ovoga rada djelomično vidimo, Boranić je u početcima karijere dosta pisao i o hrvatskoj književnoj povijesti, a bavio se i prevođenjem. U JAZU-u je od 1926. do 1941. djelovao kao književni tajnik. Bio je vrlo angažiran kao dugogodišnji i marljiv urednik Zbornika za narodni život i običaje Južnih Slavena (usp. Čulinović-Konstantinović 2000), gdje imamo i nešto njegove suradnje, a kraće vrijeme Boranić je uređivao i Nastavni vjesnik. Bio je urednikom dvaju terminoloških rječnika (Zoološka terminologija i nomenklatura, Beograd, 1932; Botanička terminologija, Beograd, 1934), također je sudjelovao u odobravanju za tisak Akademijina Rječnika. Njegov prilog o Grguru Čevapoviću kao prethodniku ilirizma u Slavoniji kratak je ali vrlo znatan prinos, a osobito je vrijedan po profinjenu tumačenju hrvatske jezične povijesti potkraj 18 . i u prvoj polovici 19. stoljeća te u doba kada je on svoj članak napisao i kad je hrvatski standardni jezik definitivno standardiziran. Kao što je poznato, do ostvarene standardnosti došlo je prvenstveno naporima Ivana Broza, Tome Maretića i Franje Ivekovića, pisaca pravopisa, gramatike i rječnika. Vidimo iz njegova rada kako se standardizacija nakon ranijih začetaka u četvrtom razdoblju hrvatske jezične povijesti (1750-1835; Brozović 2008) nastavlja i kako je u tim standardizacijskim procesima važno mjesto pripalo Grguru Čevapoviću. To je danas već dobro osvijetljeno, ali bez potrebne vrlo podrobne raščlambe jezičnih činjenica mnogih pisaca toga doba. 


\section{LITERATURA}

Babić, Stjepan. 1990. Jezik i stil Grge Čevapovića (prema djelu Josip sin jakoba patriarke. U: Zbornik radova ofra Grguru Čevapoviću. Znanstveni skup ofra Grguru Čevapoviću s izložbom njegovih djela i rukopisa [ur. Dragutin Tadijanović, Josip Vončina, Dušan Čalić]. Osijek: JAZU, 135-145.

Batušić, Nikola. 1990. Dramska struktura Čevapovićeva Josipa, sina Jakoba patriarke. U: Zbornik radova o fra Grguru Čevapoviću. Znanstveni skup o fra Grguru Čevapoviću s izložbom njegovih djela i rukopisa [ur. Dragutin Tadijanović, Josip Vončina, Dušan Čalić]. Osijek: JAZU, 93-104.

Boranić, Dragutin. 1899. Prethodnik ilirizma u Slavoniji. "Smotra dalmatinska", 12, $10,1-2$.

Bratulić, Josip. 1992. Grgur Čevapović. U: Grgur Čevapović, Josip, sin Jakoba patriarke. Zagreb: Otvoreno sveučilište, 3-21.

Brozović, Dalibor. 1969. Djelo Petra Zoranića u razvitku jezika hrvatske književnosti. "Zadarska revija", 18, 5, 477-494.

Brozović, Dalibor. 2008. Povijest hrvatskoga književnog i standardnoga jezika. Zagreb: Školska knjiga.

Čevapović, Grgur. 1992. Josip, sin Jakoba patriarke. Za tisak pripremio i pogovor napisao Josip Bratulić. Zagreb: Otvoreno sveučilište.

Čulinović-Konstantinović, Vesna. 2000. Etnografska istraživanja u Dalmaciji do početka 20. stoljeća. "Ethnologica Dalmatica", 9, 27-39.

Krstić, Kruno. 1942. Poviestni put hrvatskoga književnog jezika. "Hrvatska revija”, 15, 8, 412-420.

Lončarić, Mijo. 1990. Čevapovićev jezik i požeški govor. U: Zbornik radova o fra Grguru Čevapoviću. Znanstveni skup o fra Grguru Čevapoviću s izložbom njegovih djela i rukopisa [ur. Dragutin Tadijanović, Josip Vončina, Dušan Čalić], Osijek: JAZU, 147-153.

Maretić, Tomo. 1910. Jezik slavonskijeh pisaca. Prilog istoričkoj gramatici hrvatskoj ili srpskoj. "Rad JAZU", 180, 146-233.

Pavličić, Pavao. 1996. Stih i strofa u Čevapovićevu Josipu, sinu Jakoba patriarke. "Dani hvarskog kazališta", 22, Split: Književni krug, 155-185.

Samardžija, Marko. 2001. Predgovor. U: Franjo Iveković, Ivan Broz, Tomo Maretić, Vatroslav Rožić, Milan Rešetar, Antun Radić, Nikola Andrić, Dragutin Boranić. "Jezikoslovne rasprave i članci". Zagreb: Matica hrvatska, 475-487.

Scherzer, Ivan. 1896. Josip, sin Jakoba od G. Čevapovića. "Nastavni vjesnik", 4, 151-158.

Silić, Josip. 1993. Dragutin Boranić (1870-1955). U: Portreti hrvatskih jezikoslovaca [ur. Gordana Crnković], Zagreb: Hrvatski radio, 175-182.

Zbornik radova o fra Grguru Čevapoviću. Osijek: JAZU, 1990. 


\section{SUMMARY \\ GRGUR ČEVAPOVIĆ AND DRAGUTIN BORANIĆ}

The paper aims to describe the work of Grgur Čevapović (1786 - 1830), the Croatian writer from the first half of the $19^{\text {th }}$ century, and of the Croatian linguist Dragutin Boranic (1876 - 1955), who in the early phase of his career very lucidly evaluated Čevapović and his Croatian language.

Boranić concluded that Čevapović had written in the language which was mostly used by the Croats in his time too (1898), but this fact has remained insufficiently recognized up to the present time. Obviously, Grgur Čevapović had a very significant position in the standardisation processes of the Croatian language at the end of the $18^{\text {th }}$ and at the beginning of the $19^{\text {th }}$ centuries but neither his nor Boranić's positions have been sufficiently noticed in that context.

Key words: Čevapović, Boranić, drama, Croatian standard language 